\title{
BREEDING OF NEW PEAR WINTER CULTIVAR 'PANDORA'
}

\author{
N. Braniște ${ }^{1}$ and M. Militaru ${ }^{*}$ \\ 1Research Institute for Fruit Growing Pitești, Romania \\ *Corresponding author email: mmilitaru@icdp.ro
}

\begin{abstract}
Psylla and fire blight resistance combined with fruit quality are still pearbreeding aims at Research Institute for Fruit Growing (RIFG) Pitești, Romania. The new pear cultivar 'Pandora' was registered in 2019 , being released by interspecific hybridization between 'Euras' cv. [(PyrusserotinaxOlivier de Serres) $x$ Doyenne d'hiver] and 'Tse Li' cv. (P.ussuriensis). The trees are medium vigor, weak branching and semi-upright habit being productive and with low tendency to biennial bearing. The fruit ripens 10-15 days earlier than 'Euras', at end of September.Fruit weight is about $250 \mathrm{~g}$, flesh is yellowish white, fine, crisp, juicy, sweetand flavored. The skin color changes from green to yellow upon maturity. It is highly resistant to fire blight and pear psylla under the standard spraying program. Therefore, this new cultivar shows a good potential for commercial fruit growing.
\end{abstract}

Keywords: breeding, Pyrus, resistance, description.

\section{INTRODUCTION}

'Pandora' is a new winter cultivar released from the pear breeding program of Research Institute for Fruit Growing (RIFG) Pitești, Romania. It is a long storage cultivar, very attractive and flavored. It is resistant to fire blight and pear psylla under the standard spraying program.

The pear breeding program started in 1967 at RIFG Pitești andhad as objectives new cultivars with high quality fruit and resistance to fire blight (Erwinia amylovora Burill), tolerance to fumagine (Capnodium salicinum) and pear psylla.Twelve dessert pear cultivars have already been released: 'Trivale' (1982), 'Triumf' (1983), 'Argessis' (1985), 'Daciana', 'Carpica' (1989), 'Getica', 'Monica' (1994), 'Ervina' (2003), 'Paramis' (2008), 'Paradise', 'Paradox' (2010), 'Isadora' (2012). 'Monica'is favored for its appearance and 'Daciana' for its taste.

Interspecific hybridization of Pyrus has been released by RIFG Pitești since 1991, when the fire blight disease spread in pear orchards for the first time. The breeding strategy involves the intercrossing of European (P. communis Linn.), Japanese (P. pyrifolia Nakai) and Chinese (P. bretschneideri Rehd.) in order to combine buttery juicy texture with crisp texture, sweet and strong flavor, to extend storage period, to increase the resistance to pests and diseases. The interspecific hybridization is still consider a method with great potentialof pear breeding especially for ripening season extension, fruit quality, disease resistance and cold hardiness (Layne, 1997).

\section{MATERIALS AND METHODS}

'Pandora' was obtained by artificial pollination between 'Euras' cv. (registered in 1994, by Research Station for Fruit Growing Voinesti, Romania, authors: NistorAndrieș and Gheorghe 
Moruju) and 'Tse Li' cv. (synonym 'Tsu Li' or 'Su Li', an ancient pear cultivar from Shandong, China, introduced at Research Institute for Fruit Growing Pitești in 1994, from USA,by CociuVasile) made in 2003. The pedigree of interspecific hybridization of 'Pandora' is shown infigure 1. Seedlings were raised in 2004 and planted in selection filed, on own roots, in 2005. The seedlings began to crop in 2011 and the hybrid tree was selected as a promising one in 2013. The new cultivar was registered in 2019 by the State Institute for Variety Testing and Registration with certificate number 9730/24.10.2019, authors: N. Braniște and Mădălina Militaru.

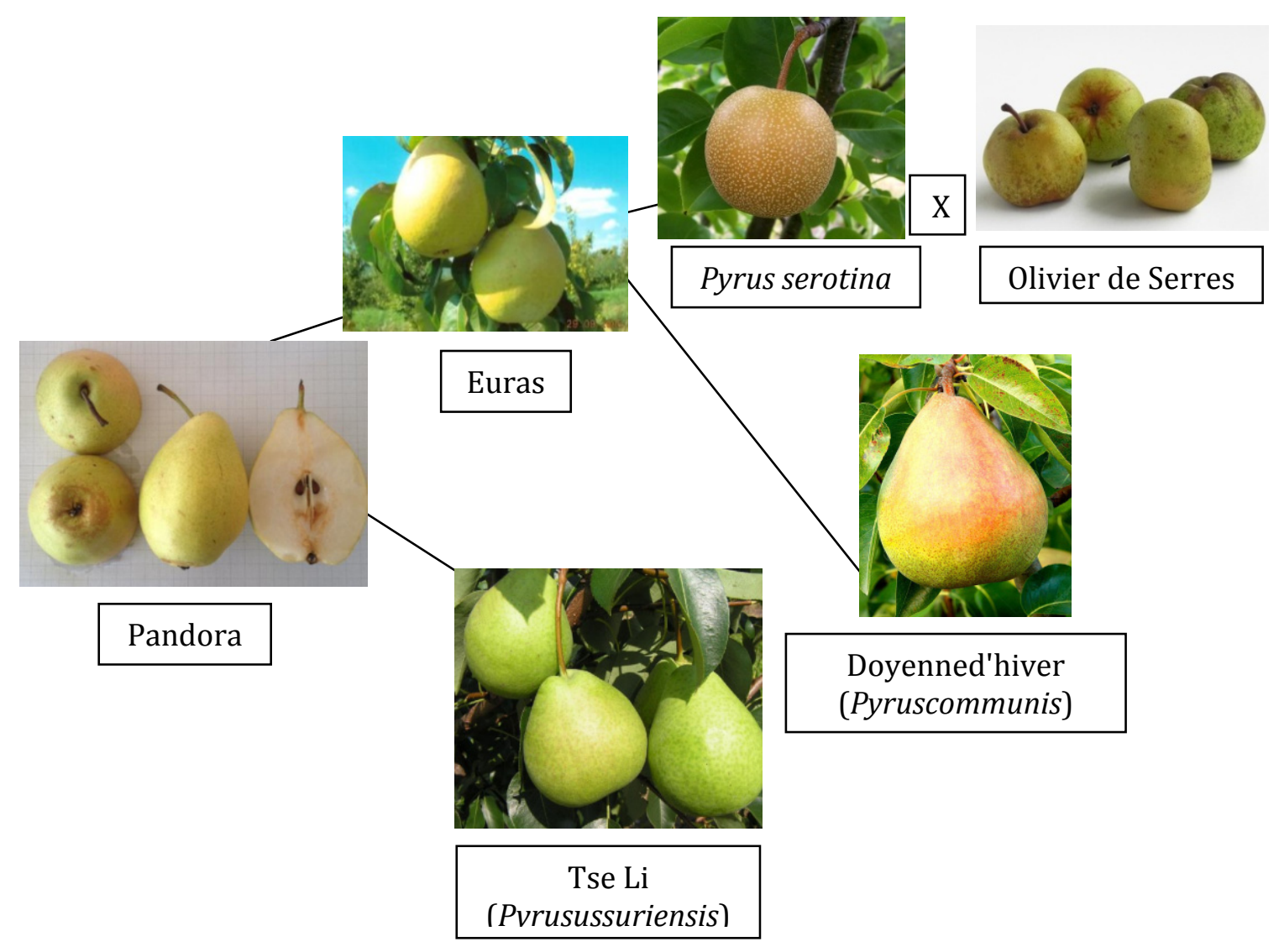

Figure 1. Pedigree of 'Pandora'cv.

\section{RESULTS AND DISCUSSIONS}

\section{Tree}

The habit is semi-upright with medium vigor. The fruit cropping is generally high and regular every year. Even after a high cropping season, the tendency toward biennial bearing is very low. The vegetative buds are big size and shape of apex is obtuse. The leaf blade is $9.96 \mathrm{~cm}$ in length, $5.66 \mathrm{~cm}$ in width and $2.5 \mathrm{~cm}$ length of petiole. The incisions of margin of leaf blade are bluntly serrate. The corolla is $3.4 \mathrm{~cm}$ in diameter and white. Most of flowers have 5 petals and a few flowers have 6-7 petals. The petals are large (15.4 $\mathrm{mm}$ in length and $10.5 \mathrm{~mm}$ in width) and circular in shape (Table 1, Fig. 2a).

\section{Fruit}

'Pandora' fruit is large, about $250 \mathrm{~g}$ weight as average (for young trees, 280-300 g/ fruit), $8.7 \mathrm{~cm}$ length, $7.3 \mathrm{~cm}$ the maximum diameter and ratio length/diameter is 1.2.The fruit stalk is $3.21 \mathrm{~cm}$ in length and $2.8 \mathrm{~mm}$ in thickness (Table 2, Fig. 2b). At harvest, the 
depth andwidth of eye basin are medium, $11.08 \mathrm{~mm}$ depth and $26.55 \mathrm{~mm}$ width, respectively. The flesh is yellowish white, fine, crisp, juicy, sweet, strongly flavorful and typical aroma with few grit cells. The juiciness varied from juicy to very juicy, depending on the maturity stage. The soluble solids content is $16.8 \%$ Brix, higher than 'Euras' cv. Fruits of 'Pandora' has a green ground color at harvest, which changes into yellow after storage.

\section{Flowering and harvest time}

Flowering occurs a few days along about a week, before 'Monica' and 'Euras'cvs. Harvest maturity is the same as 'Monica' cv. (end of September in Pitești, Argeș), but one month earlier than 'Euras' cv. Fruit mature homogeneously within the tree, so that only two pickings are required. 'Pandora' $\mathrm{cv}$. is not susceptible to preharvest drop and the storage ability is excellent, the fruits keepingbeing 120-130 days under cold storage. Fruit picked too early, after long storage, can show some brown core and sometimes flesh browning. The shelf life of 'Pandora' proved to be good: stored until January at $1^{\circ} \mathrm{C}$, the shelf life period was about two weeks.

Table 1. Cultivar description using UPOV guidelines

\begin{tabular}{|c|c|c|c|}
\hline $\begin{array}{l}\text { No. } \\
\text { UPOV }\end{array}$ & Characteristics & States of expression & Note \\
\hline 1 & Tree: vigor & medium & 5 \\
\hline 2 & Tree: branching & weak & 3 \\
\hline 3 & Tree: habit & semi-upright & 3 \\
\hline 4 & One year old shoot: growth & zig-zag & 3 \\
\hline 5 & One year old shoot: length of internode & long & 7 \\
\hline 6 & One year old shoot: predominant color on sunny side & brown red & 5 \\
\hline 7 & One year old shoot: number of lenticels & many & 7 \\
\hline 8 & One year old shoot: shape of apex of vegetative bud & obtuse & 2 \\
\hline 9 & $\begin{array}{l}\text { One year old shoot: position of vegetative bud in } \\
\text { relation to shoot }\end{array}$ & markedly held out & 3 \\
\hline 10 & One year old shoot: size of bud support & large & 7 \\
\hline 11 & $\begin{array}{l}\text { Young shoot: anthocyanin coloration of growing tip } \\
\text { (during rapid growth) }\end{array}$ & weak & 3 \\
\hline 12 & Young shoot: intensity of pubescence (upper third) & strong & 7 \\
\hline 13 & Leaf blade: attitude in relation to shoot & outwards & 2 \\
\hline 14 & Leaf blade: length & long & 7 \\
\hline 15 & Leaf blade: width & medium & 5 \\
\hline 16 & Leaf blade: ratio length/width & large & 7 \\
\hline 17 & Leaf blade: shape of base & obtuse & 3 \\
\hline 18 & Leaf blade: shape apex (excluding pointed tip) & right-angled & 2 \\
\hline 19 & Leaf blade: length of pointed tip & medium & 5 \\
\hline 20 & Leaf blade: incisions of margin (upper half) & bluntly serrate & 3 \\
\hline
\end{tabular}




\begin{tabular}{|c|c|c|c|}
\hline $\begin{array}{c}\text { No. } \\
\text { UPOV }\end{array}$ & Characteristics & States of expression & Note \\
\hline 21 & Leaf blade: depth of incisions of margin & shallow & 3 \\
\hline 22 & Leaf blade: curvature of longitudinal axis & medium & 5 \\
\hline 23 & Petiole: length & medium & 5 \\
\hline 24 & Petiole: presence of stipule & absent & 1 \\
\hline 26 & Shoot: location of flower bud & mainly on spurs & 1 \\
\hline 27 & Flower bud: length & long & 7 \\
\hline 28 & Flower: sepal length & long & 7 \\
\hline 29 & Flower: attitude of sepals in relation to corolla & adpressed & 1 \\
\hline 30 & Flower: position of margins of petals & overlapping & 3 \\
\hline 31 & Flower: position of stigma in relation to stamens & above & 3 \\
\hline 32 & Flower: size of petal & large & 7 \\
\hline 33 & Flower: shape of petal (excluding the claw) & circular & 1 \\
\hline 34 & Flower: shape of base of petal (excluding the claw) & truncate & 3 \\
\hline 36 & Immature fruit: color of sepals (early summer) & green-brown & 2 \\
\hline 37 & Fruit: length & long & 7 \\
\hline 38 & Fruit: maximum diameter & large & 7 \\
\hline 39 & Fruit: ratio length/diameter & large & 7 \\
\hline 40 & Fruit: position of maximum diameter & clearly towards calyx & 3 \\
\hline 41 & Fruit: size & very large & 9 \\
\hline 42 & Fruit: symmetry (in longitudinal section) & strongly asymmetric & 3 \\
\hline 43 & Fruit: profile of sides & convex & 3 \\
\hline 44 & Fruit: ground color of skin & green & 2 \\
\hline 45 & Fruit: relative area of over color & absent or very small & 1 \\
\hline 48 & Fruit: relative area of russet on cheeks & small & 3 \\
\hline 49 & Fruit: relative area of russet around stalk attachment & absent or very small & 1 \\
\hline 50 & Fruit: length of stalk & medium & 5 \\
\hline 51 & Fruit: thickness of stalk & medium & 5 \\
\hline 52 & Fruit: curvature of stalk & absent or very weak & 1 \\
\hline 53 & Fruit: attitude of stalk in relation to axis of fruit & oblique & 2 \\
\hline 54 & Fruit: depth of stalk cavity & deep & 7 \\
\hline 55 & Fruit: attitude of sepals (at harvest) & converging & 1 \\
\hline 56 & Fruit: eye basin (at harvest) & present & 9 \\
\hline 57 & Fruit: depth of eye basin (at harvest) & medium & 5 \\
\hline 58 & Fruit: width of eye basin (at harvest) & medium & 5 \\
\hline
\end{tabular}




\begin{tabular}{|c|l|c|c|}
\hline $\begin{array}{c}\text { No. } \\
\text { UPOV }\end{array}$ & \multicolumn{1}{|c|}{ Characteristics } & States of expression & Note \\
\hline 59 & Fruit: relief of area around eye(at harvest) & smooth & 1 \\
\hline 60 & Fruit: texture of flesh & medium & 5 \\
\hline 61 & Fruit: firmness of flesh & firm & 7 \\
\hline 62 & Fruit: juiciness of flesh & elliptic & 3 \\
\hline 63 & Seed: shape & very early & 1 \\
\hline 64 & Time of beginning of flowering & late & 7 \\
\hline 65 & Time of maturity for consumption & & \\
\hline
\end{tabular}

Table 2. Fruit characteristics of 'Pandora' on 2016-2018 at RIFG Pitești

\begin{tabular}{|c|c|c|c|c|c|c|}
\hline Cultivar & $\begin{array}{c}\text { Mean fruit } \\
\text { weight (g) }\end{array}$ & $\begin{array}{c}\text { Total soluble } \\
\text { solids (Brix, \%) }\end{array}$ & $\begin{array}{c}\text { Titrable } \\
\text { acidity } \\
\text { (\%) }\end{array}$ & $\mathbf{p H}$ & $\begin{array}{c}\text { Duration } \\
\text { of storage } \\
\text { (days) }\end{array}$ & $\begin{array}{c}\text { Yield* } \\
\text { (kg tree-1) }\end{array}$ \\
\hline Pandora & $250 \mathrm{a}$ & $16.8 \mathrm{a}$ & $0.60 \mathrm{a}$ & $5.24 \mathrm{a}$ & $125 \mathrm{a}$ & $16.78 \mathrm{a}$ \\
\hline Euras & $156 \mathrm{c}$ & $14.6 \mathrm{~b}$ & $0.52 \mathrm{a}$ & $4.92 \mathrm{~b}$ & $140 \mathrm{~b}$ & $13.86 \mathrm{~b}$ \\
\hline Monica & $175 \mathrm{~b}$ & $12.8 \mathrm{c}$ & $0.48 \mathrm{a}$ & $3.94 \mathrm{c}$ & $106 \mathrm{c}$ & $15.62 \mathrm{a}$ \\
\hline
\end{tabular}

*Values are the mean for 4 to 6 year old trees, grafted on Pyruscommunis seedlings

The different letter indicates significant differences between means according to Duncan's multiple range test, $\mathrm{P} \leq 0.05$

\section{Pest and disease susceptibility}

During 2016-2018, period of observation, no symptoms of fire blight and psylla.

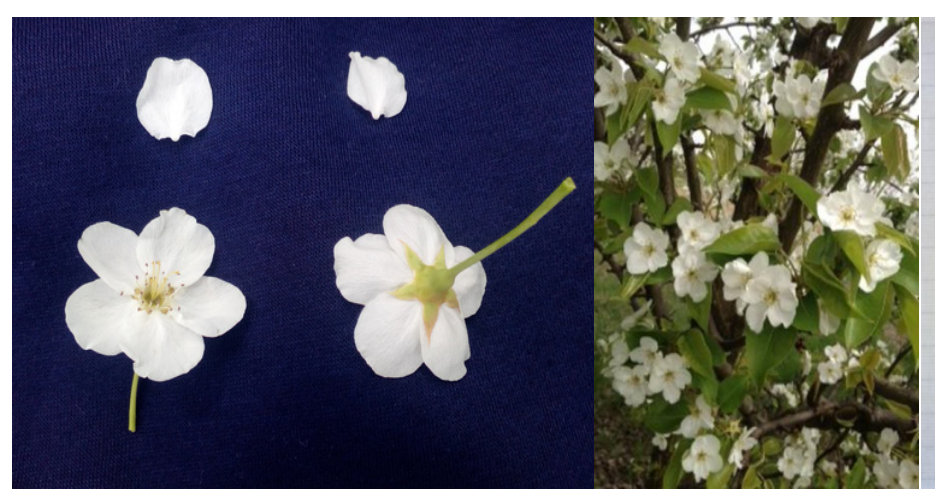

a.

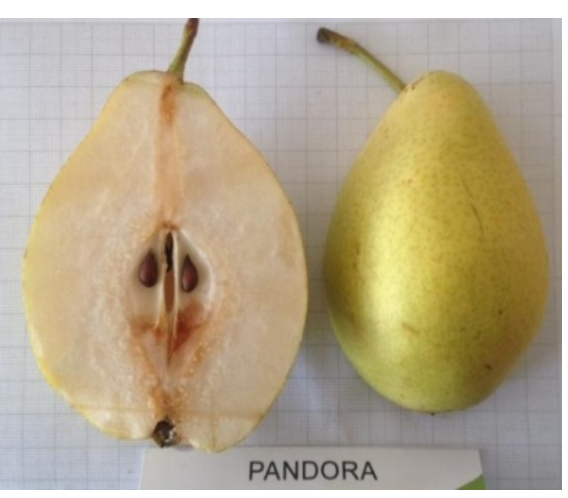

b.

Figure 2. 'Pandora' flowers (a) and fruits (b)

\section{CONCLUSIONS}

- 'Pandora' produced attractive fruits, with crispy, juicy and tasty flesh, a good storability and a very good shelf life.

- It is licensed in Romania by the State Institute for Variety Testing and Registration and is presently available from RIFG Pitești nursery. 


\section{REFERENCES}

1. Andreieș N. and Erculescu M. (2011). Pear tree cultivars obtained at the Research Station for Fruit Growing Voinești, Scientific papers RIFG Pitești, vol. XXVII

2. Cociu V. (2017). Contribuții ale specialiștilorromâni la sporireașivalorificareadiversitățiipomicole, prinintroducerea de genotipuristrăineînperioada 1950-2008 (Iași: Pim ed.), p. 67, p. 126,

3. ISTIS (2019). Raport de examinaretehnicănr. 09052

4. Layne, R. E. C. (1997). Hybridization. In Methods in Fruit Breeding, J. Janick and J. N. Moore (eds.), p. 45-62

5. UPOV (2011). Guidelines of the Conduct of Tests for Distinctness, Uniformity and Stability. Pear (Pyruscommunis L.). UPOV, TG /15/2, Geneva

6. Ștefan N., Glăman Gh., Braniște N., Stănică Fl., Duțu I., Coman M. (2018). Soiuri de păr. In PomologiaRomâniei, vol. IX, p. 333-339 